DOI: https://doi.org/10.34069/AI/2021.44.08.26

How to Cite:

Khromov, A.V., Gadzalo, I., Abroskin, V.V., \& Zavalnyi, M.V. (2021). Perspectives of public administration's development: International experience. Amazonia Investiga, 10(44), 270-277. https://doi.org/10.34069/AI/2021.44.08.26

\title{
Perspectives of public administration's development: International experience
}

\section{Перспективи розвитку публічного адміністрування: міжнародний досвід}

Received: July 19, 202

Abstract

The purpose of this article is to reveal the urgent state of affairs in the sphere of public administration in Ukraine and the world. The most relevant problematic issues in regard to the functioning of public administration area have been also studied. The current prospects for the development of public administration are characterized. In particular, successful examples of international experience in this field are analyzed. Methods of public administration in a number of developed countries are also compared. The meaning of the terms "public administration", "implementation of public administration" and "development of public administration" is revealed. It is noted that the importance of understanding exactly how to carry out public administration within a particular state or a particular region or municipality is a key factor in the success and effectiveness of a political program of any political force. The importance of active cooperation of state authorities of Ukraine, as well as the public, with Ukraine's international allies and partners is emphasized. After all, it is fruitful interaction with such states that will help Ukraine to develop faster and acquire the useful qualities and properties that it must possess in
Accepted: September 20, 2021

Written by:

Anatolii Volodymyrovych Khromov ${ }^{106}$ https://orcid.org/0000-0002-9546-7089

Iaroslav Gadzalo ${ }^{107}$ https://orcid.org/0000-0002-5028-2048

Viacheslav Vasiliievich Abroskin ${ }^{108}$ https://orcid.org/0000-0002-4062-8105

Mykhailo Volodymyrovych Zavalnyi ${ }^{109}$ https://orcid.org/0000-0003-4191-061X

\section{Анотація}

Метою статті є розкриття актуального стану справ у сфері публічного адміністрування в Україні й у світі. Також розглядаються найбільш гострі проблемні питання відносно функціонування галузі публічного адміністрування. Характеризуються наявні на сьогоднішній день перспективи розвитку публічного адміністрування, зокрема, аналізуються успішні приклади міжнародного досвіду у цій сфері та порівнюються методики здійснення публічного адміністрування у низці розвинутих країн світу. Розкривається зміст понять «публічне адміністрування», «здійснення публічного адміністрування» i «розвиток публічного адміністрування». Аналізується специфіка здійснення публічного адміністрування у країнах, на які Україна прагне бути схожою. Зазначається, що важливість розуміння того, як саме здійснювати публічне адміністрування у межах конкретної держави або конкретного регіону чи муніципалітету, $\epsilon$ ключовим фактором успішності та ефективності реалізації тієї чи іншої політичної програми будь-якої політичної сили. Окремо підкреслюється важливість активної співпраці органів державної влади України, а також громадськості, із міжнародними союзниками та

\footnotetext{
${ }^{106}$ Candidate of Historical Sciences, Head of the State Archival Service of Ukraine, Ukraine.

${ }^{107}$ Doctor of Agricultural Sciences, Professor, Academician of the National Academy of Agrarian Sciences of Ukraine, President of NAAS of Ukraine, Ukraine.

$108 \mathrm{PhD}$ in Law, Rector of Odessa State University of Internal Affairs, Ukraine

${ }^{109}$ Doctor of Jurisprudence, Senior Researcher, Associate Professor of the Department of Administrative Law and Process of the Faculty No. 1 of Kharkiv National University, of Internal Affairs, Ukraine.
} 
order to effectively carry out public administration.

Key words: public administration, correct policy, legal support, public services.

партнерами України. Адже саме плідна взаємодія 3 такими державами допоможе Україні розвиватися більш швидко і набути ті корисні якості i властивості, якими вона повинна володіти задля ефективного здійснення публічного адміністрування.

Ключові слова: публічне адміністрування, коректна політика, правове забезпечення, публічні послуги.

\section{Introduction}

The issue of the development of electronic space in the conditions of the modern globalization and information world acquires special urgency at present time. This indisputable fact actualizes the study of a set of problems that have a direct impact on the development of society. First of all, it concerns the issues of improving the efficiency of public institutions' activities, including executive agencies and local self-government, through the introduction of information and communication technologies based on egovernment (Tsybulnyk et al., 2020). The vast majority of countries seek to achieve greater efficiency in the field of public administration in accordance with the current world tendencies. The quality and efficiency of the implementation of direct public and administrative functions by state agencies and institutions, as well as local self-government agencies, directly depends on a number of equally important factors. Such factors are the political regime in the country, the level of its economic development and the level of transparency of the state system. In addition, issues related to the legal regulation of public administration area by the state are influential.

According to a number of scientific studies, the current system of public administration in Ukraine remains inefficient, corrupt and internally contradictory, which is a significant obstacle to positive changes in society and the state. Insufficient level of transparency and openness in public administration area, unclear distinction between political and administrative spheres, insufficient professional level of state officials, lack of a unified system for assessing their competence, low level of disciplinary liability, imperfect mechanism of political and administrative control within public administration system - all these factors are destructive elements in the organization of an effective system of public administration. Thus, according to the Global Competitiveness Index 2017-2018 published by the World Economic Forum, Ukraine ranked 81st among 137 countries in 2018 , improving its position by only

four points. According to the study data, Ukraine has worsened its position in 4 out of $12 \mathrm{key}$ indicators. Mostly it has lost (minus 13 points) on the component of "Labor market efficiency". The tendency to worsen this indicator has been observed in the studies of the last year (Bobko, 2018).

Thus, those factors play a significant role both in improving the quality of public administration, if they are in a well-developed state, and hinder the implementation of effective public administration in case of their underdevelopment. Taking into account this fact the authors have paid considerable attention to the above and other components of the processes related to the implementation of public administration in Ukraine and other countries of the world.

\section{Methodology}

The article was written based on the bibliographic method, the use of which made it possible to study the literature behind the topic of the article and draw appropriate conclusions. Data collection was carried out through two techniques: document analysis and observations, followed by data reduction, data display, and conclusion. Mixed methods of data collection were utilized which enabled the researchers to collect both primary and secondary data. For a secondary source of data literature was consulted for the study.

The bibliographic method includes a qualitative selection of documents, assuming the formulation of appropriate criteria, focus on requests and interests. Any scientific research (both collective and individual) begins with an analysis of the flow of documents on the topic under study and ends with the compilation of a bibliographic list. Methods of grouping bibliographic information, building it in a different sequence (systematic, thematic, logical, chronological, alphabetical, linguistic, etc.), 
make it possible to characterize the problem under study in different ways.

The comparative analysis provided an opportunity to identify different approaches to the perspectives of public administration development. This fact is fully explainable since many scholars were interested in the perspectives for the development of electronic litigation. Some of them have paid serious attention to that matter, having accomplished in-depth research on that topic, as evidenced by the authors' own approaches to the innovative development of public administration, which is essential for further successful improvement of public administration and public activities. A significant contribution to the development of those issues has been made by well-known experts, who consider public administration as the priority key issue. They combine, in their research, world experience, knowledge of political realities and modern practice - approaches, principles and values, as well as the formation and development of public administration in Ukraine.

\section{Literature Review}

N. Nyzhnyk (2008) defined the system of public administration as a set of specialized subjects and procedures of managerial influence, which ensures the existence of society within a certain area and is organized around an institutionalized center and performs most of the coordination activities, distributes management functions and guarantees their implementation. The scholar emphasizes that public administration should be considered through the principles, where special attention is paid to the role and importance of personnel in the system of public authority and public administration.

O. Obolenskyi (2009) considers theoretical approaches and the sphere of public administration through the foundations of democratic principles. Public administration according to this author should be understood as managerial influence - a tangible interaction of the state apparatus and society in making important decisions, actions for the country (society, population), as an open public sphere of public interest, where all public institutions, citizens can be both the objects of management and can act as subjects, autonomous units in relations with authorities and management.

O. Zimina (2011) notes that taking into account the experience of developed countries of Western democracies, we should focus on elaborating a strategy of development for Ukraine for the next ten years, making it impossible to revise it under the pressure of political conditions. The concept of public administration and the law on public service should become the key component of Ukraine's development strategy. This will facilitate the improvement of state institutions' activities and will enable civil society to participate in management decisions, taking into account the experience of developed countries. All the above measures will contribute to the efficiency and effectiveness of the reproduction of the democratic essence of the young independent state of Ukraine.

It is worth noting the monographic study on "Public management and administration in terms of information society: domestic and international experience", authored by S. Chernov, V. Voronkova, V. Banakh, (2016). That paper provides a conceptual analysis of public management and administration, the subject matter of which is the analysis of economic, social and political processes occurring in the public sphere, and the object is theoretical, methodological and methodical foundations of management in the public sphere. The authors presented domestic and international experience of public management and administration, presented by the experience of Europeanization of public management and administration of post-communist countries of Central and Eastern Europe, as well as the impact of this process on public management and administration in Ukraine. The authors also presented the experience of Lithuania, which demonstrates the European level of public management and administration based on the practical implementation of the "good governance" principles, which is an effective experience of public management and administration.

The textbook, edited by O. V. Skydan (2017), determines methodological approaches to administration in public management, establishes the role and importance of administration in the systems of legislative, executive and judicial power. The authors focused their attention on the economic and administrative role of state executive agencies in ensuring social development in terms of existing threats to national security. According to the researchers, the management of territorial development and the formation of local identity is of particular importance in the context of decentralization, and it is necessary to focus on the application of world practices, especially communications in the public sphere and specifics of psychology during the reform of 


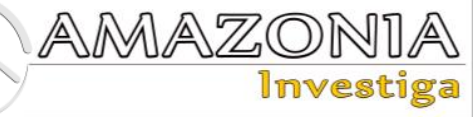

public administration. Scholars have defined public administration as a holistic structured process that is part of public (state) governance (management), which is carried out by a set of state authorities and local self-government agencies in order to ensure sustainable and comprehensive development of the state in the whole and its certain regions on the basis of effective use of modern management methods and mechanisms based on the principles of democracy, legality and the rule of law, the priority of human rights, as well as the effective use and distribution of available state resources, which allows to ensure social equality and a high level of public needs.

K. L. Bugaychuk (2018) studied theoretical approaches to the definition of the essence and characteristics of public administration, its relationship with state and public administration, and the management process. In our opinion public administration is regulated by laws and other system organizing normative legal acts, power and regulatory activities of state authorities and local self-government, which is aimed at streamlining their organizational structure, planning, preparation, development and implementation of managerial decisions, organization of the management apparatus, the implementation of documentary, information, personnel, and psychological support of their daily activities in order to achieve socially useful goals and the creation and operation of the relevant entity of administration.

\section{Result and Discussion}

It should be recognized that the main reason for the constant desire of citizens of different countries to constantly improve management in both public and private sectors has its roots from the ancient times. According to scholars, it is completely natural that individuals want management processes related to the organization of certain works or the provision of certain services to become more efficient over time and require minimum expenditures.

Thus, society's need to increase the efficiency of public administration processes is based on the natural and historical necessity of people to receive services of better quality and the need for effective leadership. In other words, it is based on the constant need of individuals for progress and development (Mosher et al., 2020).

If we study the functioning of public administration more thoroughly, we can note that one of the key elements for the effective public administration (for example, the provision of public services) is the fact what is the political regime in the country, which public administration is studied.

In fact, we should state that the development of public management and administration depending on the peculiarities of the existence of a particular political regime in a particular country under specific conditions can be both rapidly accelerated and become a major factor in the decline of this area for a long period of time (OECD, 2008).

International experts state that the quality of the functioning of the processes related to the implementation of public administration by state authorities is generally much better in states whose political regime is generally called democratic and legal. Herewith, all actions of government agencies and institutions in such a regime will be taken in the interests of the entire society, all citizens of the state, thereby increasing their well-being and resolutely protecting their rights and interests.

On the contrary, the authoritarian regime is interested only in those actions that will strengthen its further power. Therefore, the actions of state authorities under the authoritarian regime do not demonstrate a real interest in the development of service function of the state in relation to all its citizens (European Union, 2017).

According to an authoritative British resource, the well-known English-language encyclopedia Britannica, which has been continuously existed, updated and published since 1768 and to the present time, public administration generally consists of the activities of various agencies and institutions of a state and local self-government, which consists in providing citizens with justice, financial institutions and security.

British and American scholars also add that the processes related to the provision of public services to the country's citizens are extremely important and one of the main elements of public administration. It has been stated that such public services are extremely diverse and must meet the basic, if not all, needs of individuals for the realization of their rights and legitimate interests. It should be noted that the prototypes of such a "service" policy towards citizens were elements of the activities of state authorities of the countries of the Ancient World. 
It is especially true of the Ancient Rome, where such a policy received its greatest development and practical implementation. Numerous magistrates, which were responsible for one or another direction for the organization of the state and society's functioning, had to perform their direct work well and qualitatively, providing the population with the necessary conditions to realize their rights and meet their daily needs in many spheres of public life.

Subsequently, theoretical justification and practical implementation of the above processes have been developed to a higher level. Actions on improving the existing state system were taken with the development of democratic and liberal movements and processes in different countries of the world, as well as with a marked increase in the level of well-being of some states (United Nations, 2019).

In particular, many attempts have been made, including successful ones, to standardize the sphere of public administration, to overcome the negative factors of bureaucracy, as well as to increase the efficiency of government agencies and institutions. It is also applied to those agencies whose direct functional task was to provide public services to representatives of various segments of the population.

Regarding the development of public management and administration, it can be argued that large empires played a significant role in the development efforts of that sphere, especially at the initial stage. We talk about such states as the British Empire, which had more than a quarter of the world's land area and more than a quarter of the world's population under its control at the height of its power.

Given such a large territorial size, which, incidentally, was not limited to one particular continent, but located in different parts of the world, as well as a huge subjugated population, the British leadership urgently needed to implement reliable mechanisms for exercising public administration in regard to each integral part of the Empire of that time (McDonald III, 2020).

It was Britain that became one of the first countries in Europe to introduce the certification of state officials for their qualifications for the position they hold. A system of decision-making autonomy was also introduced in that country. According to that system, a competent official had the right in some situations to take responsibility for making decisions independently (O'Flynn, 2021).

Fundamentally different was the development of public administration in the XX century. The United States of America took the leading position in the effectiveness of the practical implementation of public administration, as well as in theoretical validity of this field. A strong economy, the financial well-being of the vast majority of the population, the real rule of law, an independent judicial system, a stable political system - all those factors have become a reliable way to increase the efficiency of public administration in the United States (Torneo, 2020).

It should be also added that public administration since the XX century has become increasingly associated with the economic condition of the state and the level of material well-being of its representatives. Besides, the effectiveness of the public administration system has been directly linked by Western scholars to the economic growth of a particular country.

We should note that the latest ideas expressed and later formulated by American and Western European experts and researchers in the XXI century, especially in recent years, outlined several proven principles.

First of all, it was argued that a significant part of the negative and inefficient processes in the field of public administration could be successfully eliminated through the proper organization or reorganization of a particular government agency or the entire system.

It has been pointed out that many useful elements of modern public administration in the developed world countries were borrowed from the business environment and from the military organization of some Western countries, primarily from the United States. Most of those elements have indeed proven their high effectiveness in their practical application in various areas of civil service (McDonald III \& Hatcher, 2019).

International scholars and researchers of the processes associated with the implementation of public administration tend to identify several of the above organizational elements. Thus, they include, for example: the creation and organization of ministries, departments and agencies based on related or similar activities; merging units that carry out similar activities into a single structural unit; the combination of authoritative powers with responsibility, the 


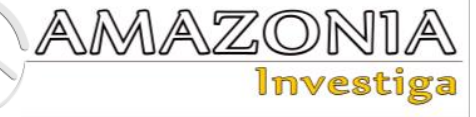

introduction of the principle of "undivided authority", when the responsibility to make key decisions has one person - the head even if there is independent control in accordance with the functioning of the unit.

Scholars also note other characteristic borrowed elements of the state systems of developed countries. Namely: making clear restrictions and definitions in regard to the matter of subordination, in particular, to whom of the middle and senior managers employees should report on their own direct activities; the division of employees into "operational line" employees who perform the direct functions of the unit or department and employees who perform advisory or support functions, mostly not related to the direct activities of the unit or department (European Union, 2018). It has been also emphasized that the functioning of modern state structural units engaged in public administration should be based on modern effective management methods. Among other things, it concerns to the application of the principle of "exception management" in government agencies, which is often used in Western private companies. The essence of this principle is that only an unusual problem or case acquires special significance and becomes a priority of the department. All other tasks must be solved in a standard mode with a clear and effective division of working time, number of employees and the amount of logistical support. Besides, it has been stated that a clear scheme of command and responsibility should be applied to the activities of units. In particular, management should be defined, hierarchical and free of redundant positions or duplication of powers. An important component of this should be the acquisition of greater autonomy in decision-making by lower and middle managers within their competence, in regard to the activities of the department or unit (Abony \& Slyke, 2020).

Instead, it is important to provide a reliable accountability mechanism that would ensure that individuals are more accountable for their careers. It is clear that the main responsibility for the activities of a state agency should be borne by the head of that state agency (Osborne, 2010).

The modern civil service should definitely consist of the best components of successful experience and successful practical examples that have proved themselves in the past. Of course, obsolete components must either be updated to meet modern requirements or, if it is not possible, be disposed of as redundant and unnecessary. It should be noted that an extremely important part of that is the transparent inspection and independent control over the activities of state officials as persons carrying out public administration, as well as the competitive selection of persons for positions in government departments and institutions.

It should be emphasized that modern mechanisms of competitive selection of persons for public positions, in particular in those public agencies that directly perform the functions of public management and administration, are logical results of the development of former systems of certification of state officials.

If we take into account the Western countries, such certification systems appeared there in the XIX century. And if we consider the whole world, we can say that, for example, the systems for verifying the level of knowledge, skills and abilities of state officials in China and some other Asian countries existed several centuries before. We agree that the practice of competitive selection of persons for positions in the field of public administration is and should remain one of the most important components. The high standards set in the best international practices should be definitely put forward before the competitive selection (Wal, 2013). In particular, it is applied to the transparency and publicity of such selection, the requirements for independence and impartiality of the members of the relevant commissions conducting such selections and the obligation for heads of public institutions to hire persons who have passed such a competitive selection.

An integral part of the functioning of the public administration area is the independent control over the distribution of the budget, i.e. the funds allocated for the implementation of specific programs in this area. For example, funds aimed at improving the efficiency of the process of providing citizens with certain public services (Roll, 2014). This state of affairs has long been common in developed Western countries and stably exists there. With regard to Ukraine, it should be noted that useful and effective practices of Western countries are gradually being implemented in the domestic society due to the movement towards European integration and due to the active support of Ukraine by foreign allies and partners.

It is clear that the Ukrainian state, in order to achieve the high level of quality of developed countries in the field of public administration, needs to make many more organizational and structural changes within the state system. 
Perspectives for further development of the domestic branch of public management and administration are the gradual adoption of modern international standards for the functioning of this area, along with the introduction of modern effective methods of implementation of tasks that are currently recognized as relevant (Ingrams et al., 2020; Lapuente \& Walle, 2020).

\section{Conclusions}

In the study scientists used methods of theoretical analysis and systematization to identify and specify the author's position within the studied issues. When preparing conclusions and recommendations based on the results of the study, the method of generalization was used.

Thus, the field of public administration is quite dynamic and depends on the state system, form of government and the level of democracy of public relations. The level of efficiency for the organization of the processes of public administration, in particular in the field of public administration services, will determine the further success of the entire public and administration system.

The history of the origin, formation and development of public administration is quite old, having some practices of public administration in the ancient times as their prototypes.

The economic condition of a particular state surely has a significant impact on the level of efficiency of public administration within the state. Besides, the impact of such important factors as the stability of the political system, the level of independence of the judicial system and the level of material well-being of the majority of citizens has been characterized.

Economic developed countries, and especially those with real rule of law and a high level of personal freedoms of citizens, are currently the undisputed leaders in the field of public administration. Countries such as the United States, Canada, Switzerland, Germany, Sweden, the Netherlands and others demonstrate vivid examples of their own success to all other states and are a good example for other states.

We believe that Ukraine definitely needs to make a considerable amount of organizational and structural changes and reforms in order to achieve the high global standards of public administration quality that currently exist.

\section{Bibliographic references}

Abony, G., \& Slyke, D. M. Van. (2020). Governing on the Edges: Globalization of Production and the Challenge to Public Administration in the Twenty-First Century. Public Administration Review. Special Issue on the Future of Public Administration, 70(1), 33-45. Retrieved: https://onlinelibrary.wiley.com/doi/abs/10.1 111/j.1540-6210.2010.02244.x.

Bobko, L. O. (2018). Problems of becoming and development of public administration system in Ukraine. Electronic scientific journal «State management: more sophisticated and development»,

5. http://www.dy.nayka.com.ua/pdf/5_2018/34. pdf

Bugaychuk, K. L. (2018). Public administration: theoretical basics and approaches to the definition. Law and Safety, 66(3), 38-44. Retrieved

from http://pb.univd.edu.ua/index.php/PB/article/ view/62.

Chernov, S., Voronkova, V. \& Banakh, V. (Eds.). (2016). Public Management and Administration in Terms of Information Society: domestic and international experience: monograph. Zaporizhia State Engineering Academy. Zaporizhzhia: ZDIA.

European Union (2017). Quality of Public Administration: A Toolbox for Practitioners. Luxembourg: Publications Office of the European Union. https://ec.europa.eu/esf/main.jsp?catId=3\&la ngId=en \&keywords $=\&$ langSel= $\&$ pubType $=$ 434

European Union (2018, March 22-23). Quality of Public Administration: What have we learned, what can we do better? Brussels. https://ec.europa.eu/social/main.jsp?langId= en\&catId=86\&eventsId=1308\&furtherEvent $\mathrm{s}=$ yes

Ingrams, A., Piotrowski, S., \& Berliner, D. (2020). Learning from Our Mistakes: Public Management Reform and the Hope of Open Government. Perspectives on Public Management and Governance, 3(4), 257-272.

https://academic.oup.com/ppmg/article/3/4/2 57/5721733.

Lapuente, V., \& Walle, S. Van de. (2020). The effects of new public management on the quality of public services. Governance, 33, 461-475.

https://onlinelibrary.wiley.com/doi/epdf/10.1 111/gove.12502.

McDonald III, B. (2020). Teaching in uncertain times: The future of public administration 


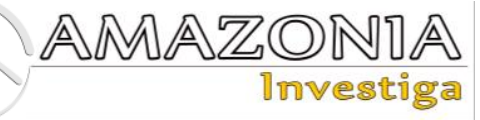

education. Teaching Public Administration, $39(1)$,

3-8.

https://journals.sagepub.com/doi/full/10.117 7/0144739420963154.

McDonald III, B.D., \& Hatcher, W. (2019). Introduction to the issue. Journal of Public Affairs Education, 25(4), 429-431, doi: 10.1080/15236803.2019.1690346.

Mosher, F. C., Chapman, B. \& Page, E.C. (2020, November 12). Public administration. Encyclopedia Britannica. https://www.britannica.com/topic/publicadministration.

Nyzhnyk, N. (2008). Public Power and Management: Principles and Mechanisms of Realization: monograph. Chernivtsi: Tekhnodruk, http://www.irbisnbuv.gov.ua/cgi-

bin/irbis_nbuv/cgiirbis_64.exe?Z21ID=\&I21 DBN=REF $\&$ P21DBN=REF $\&$ S21STN $=1 \& S$ $21 \mathrm{REF}=10 \& \mathrm{~S} 21 \mathrm{FMT}=$ fullwebr $\& \mathrm{C} 21 \mathrm{COM}=$ $S \& S 21 C N R=20 \& S 21 \mathrm{P} 01=0 \& S 21 \mathrm{P} 02=0 \& S$ 21P03 $=\mathrm{A}=\& \mathrm{~S} 21 \mathrm{COLORTERMS}=1 \& \mathrm{~S} 21 \mathrm{ST}$ $\mathrm{R}=\% \mathrm{D} 0 \% 9 \mathrm{D} \% \mathrm{D} 0 \% \mathrm{~B} 8 \% \mathrm{D} 0 \% \mathrm{~B} 6 \% \mathrm{D} 0 \% \mathrm{BD}$ $\% \mathrm{D} 0 \% \mathrm{~B} 8 \% \mathrm{D} 0 \% \mathrm{BA} \% 20 \% \mathrm{D} 0 \% 9 \mathrm{D} \$$

Obolenskyi, O. (2009, May 15-16). Predictors of a New Public Administration. Development of Public Administration on the Principles of Management: European Context: materials of scientific and practical conference. Dnipropetrovsk.

https://scholar.google.com/citations?user=Y mVWnfAAAAAJ\&hl=ru\&oi=sra

OECD (2008). Public Administration Reform: Improving Public Sector Performance. Reforms for Stability and Sustainable Growth: An OECD Perspective on Hungary. Paris: OECD Publishing, Chapter 10. https://www.oecd-

ilibrary.org/docserver/9789264043770-11en.pdf?expires $=1618268360 \& i d=i d \& a c c n a$ me $=$ guest $\&$ checksum $=09$ EF09BB74010A3 DC152EB84D60E5719.

O'Flynn, J. (2021). Confronting the big challenges of our time: making a difference during and after COVID-19. Public Management Review, 23(7), 961-980. doi: 10.1080/14719037.2020.1820273.

Osborne, S. P. (2010). The New Public Governance. London: Routledge.
https://www.routledge.com/The-New-

Public-Governance-Emerging-Perspectiveson-the-Theory-and-

Practice/Osborne/p/book/9780415494632

Roll, M. (Ed.) (2014). The Politics of Public Sector Performance: Pockets of Effectiveness in Developing Countries. London: Routledge.

Skydan, O. V. (Eds.). (2017). Public Management and Administration: manual. Zhytomyr: ZhNAEU. http://ir.znau.edu.ua/bitstream/123456789/8 495/1/Publichne_upravlinnia_2017.pdf

Torneo, A.R. (2020). Public administration education in the Philippines 1951-2020: History, challenges, and prospects. Journal of Public Affairs Education, 26(2), 127-149. https://www.tandfonline.com/doi/abs/10.108 0/15236803.2020.1744066.

Tsybulnyk, N. Yu., Zadoia, I. I., Kurbatova, I. S., \& Mekh, Yu. V. (2020). E-government within Public Administration. Jurnal Cita Hukum (Indonesian Law Journal), 8(3), 471478. doi: $10.15408 /$ jch.v8i3.18300.

United Nations (2019). World Public Sector Report 2019. New York. https://publicadministration.un.org/publicati ons/content/PDFs/World\%20Public\%20Sect or\%20Report2019.pdf

Wal, Z. (2013). Mandarins Versus Machiavellians? On Differences Between Work Motivations of Administrative and Political Elites. Public Administration Review, 73(5), 749-759. https://onlinelibrary.wiley.com/doi/abs/10.1 111/puar.12089

Zimina, O. (2011). Formation and Development of Public Management and Possibilities of Its Application in Ukraine. Collection of scientific works of the National Academy for Public Administration under the President of Ukraine, 1, 37-46. http://www.irbisnbuv.gov.ua/cgi-

bin/irbis_nbuv/cgiirbis_64.exe?I21DBN=LI $\mathrm{NK} \& \mathrm{P} 21 \mathrm{DBN}=\mathrm{UJRN} \& Z 21 \mathrm{ID}=\& \mathrm{~S} 21 \mathrm{REF}=$ $10 \& S 21 \mathrm{CNR}=20 \& \mathrm{~S} 21 \mathrm{STN}=1 \& \mathrm{~S} 21 \mathrm{FMT}=\mathrm{A}$ SP_meta\&C21COM=S\&2_S21P03=FILA= \&2_S21STR=znpnadu_2011_1_6 